\title{
Neurologic Manifestations Associated With SARS-CoV-2 Infection: A Neuro-Review of COVID-19
}

\section{Manifestaciones Neurológicas Asociadas a la Infección Por SARS-CoV-2: Una Neuro-Revisión de COVID-19}

Daniel Moreno-Zambrano,,2 Martha Arévalo-Mora, ${ }^{1,2}$ Angelina Freire-Bonifacini,

Rocío García-Santibanez, Rocío Santibáñez-Vásquez ${ }^{1}$

\begin{abstract}
Background. In December 2019, multiple cases of pneumonia of unknown etiology surged in China. In January 2020, Severe Acute Respiratory Syndrome Coronavirus 2 (SARS-CoV-2) was the identified cause. The World Health Organization (WHO) defined the condition as "Coronavirus 2019 Disease" (COVID-19). In February, its presence was confirmed in South America and Ecuador. On March 11th, the WHO declared COVID-19 as a pandemic. This condition mainly afflicts the respiratory system. However, reports of neurological manifestations in confirmed COVID-19 patients have recently emerged.

Methods. Multiple databases were reviewed, the information was extracted and analyzed independently by 3 authors.

Results. Neurological manifestations associated with COVID-19 were identified. Including: myalgia, headache, altered mental status, cerebrovascular events, dizziness, hypogeusia, hyposmia, neuropathic pain, visual impairment, ataxia, seizures, Central Hypoventilation Syndrome, encephalopathy, rhabdomyolysis, Acute Hemorrhagic Necrotizing Encephalopathy, Guillain Barre Syndrome (GBS), meningitis and encephalitis.

Conclusion. COVID-19 is associated with neurological involvement. It is most frequently observed in cases that are severe, atypical, and with comorbidities. Health care providers and neurologists alike, must remain alert and keep high suspicion of severity when these manifestations are present. Timely recognition might help initiate early treatment and isolation, preventing clinical decline and viral spread.

Keywords: Coronavirus, SARS-CoV-2, COVID-19, Neurology, Pandemic

\section{Resumen}

Antecedentes. En diciembre de 2019, múltiples casos de neumonía de etiología desconocida surgieron en China. En enero de 2020, el Coronavirus 2 del Síndrome Respiratorio Agudo Severo (SARS-CoV-2) fue identificado como su causa. La Organización Mundial de la Salud (OMS) definió la afección por este virus como "Enfermedad por Coronavirus 2019” (COVID-19). En febrero se confirmó su presencia en Sudamérica y en el Ecuador. El 11 de marzo, la OMS declaró a COVID-19 como una pandemia. Esta patología afecta principalmente al sistema respiratorio. Sin embargo, reportes de manifestaciones neurológicas en pacientes con COVID-19 han empezado a emerger.

Métodos. Múltiples bases de datos fueron revisadas, la información fue extraída y analizada independientemente por 3 autores.

Resultados. Manifestaciones neurológicas asociadas a COVID-19 fueron identificadas. Incluyendo: mialgia, cefalea, alteración de la consciencia, eventos cerebrovasculares, mareo, hipogeusia, hiposmia, neuralgia, alteración de la agudeza visual, ataxia, crisis epilépticas, Síndrome de Hipoventilación Central, encefalopatía, rabdomiólisis, Encefalopatía Necrotizante Hemorrágica Aguda, Síndrome de Guillain Barré (SGB), meningitis y encefalitis.

Conclusión. COVID-19 está asociado a compromiso neurológico. Se observa con mayor frecuencia en casos severos, atípicos y con comorbilidades presentes. Proveedores de la salud y neurólogos deben estar alertas y tener un bajo umbral de sospecha frente a estas manifestaciones. El reconocimiento oportuno de estas podría ayudar a iniciar tratamiento y aislamiento temprano, previniendo el agravamiento clínico y la diseminación del virus.
\end{abstract}

Palabras clave: Coronavirus, SARS-CoV-2, COVID-19, Neurología, Pandemia

\footnotetext{
'Universidad Católica De Santiago De Guayaquil. Guayaquil - Ecuador. ${ }^{2}$ Hospital Los Ceibos del Instituto de Ecuatoriano de Seguridad Social. Guayaquil - Ecuador.

${ }^{3}$ Universidad Espíritu Santo. Samborondón - Ecuador.

${ }^{4}$ Department of Neurology, Emory University School of Medicine.

Atlanta - United States
}

Correspondence:

Daniel Moreno-Zambrano

danielmorenozambrano@gmail.com 


\section{Introducción}

En diciembre de 2019, se identificaron casos de neumonía de etiología desconocida en la ciudad de Wuhan, provincia de Hubei en China. La causa, un nuevo betacoronavirus de ARN envuelto, que se aisló el 7 de enero de 2020, fue nombrado Coronavirus 2 del Síndrome Respiratorio Agudo Severo (SARS-CoV-2). El 11 de febrero, la Organización Mundial de la Salud (OMS) definió la afección causada por este patógeno como "Enfermedad por Coronavirus 2019" (COVID-19)! El 27 de febrero, el primer caso en América del Sur se confirmó en Brasil ${ }^{2}$ y dos días después, también se reportó el primer caso de Ecuador. El 11 de marzo, la OMS declaró a COVID-19 como una pandemia. Durante este brote, numerosos estudios han descrito principalmente síntomas respiratorios y gastrointestinales, hallazgos de laboratorio distintivos y anormalidades radiológicas pulmonares características. Pero recientemente, Mao et al realizó la primera descripción (preimpresión) en febrero 2020 (posteriormente publicada JAMA Neurology en abril), enfocándose en las manifestaciones neurológicas de la infección por SARS-CoV-2.

\section{Objetivo}

Resumir las manifestaciones y asociaciones neurológicas de la infección por SARS-CoV-2 reportadas.

\section{Métodos}

Se realizaron 3 búsquedas independientes por los autores (DMZ, MAM y AFB) de artículos publicados en inglés y español en base de datos electrónicas, incluyendo Medline, EMBASE, BEI, Cochrane Library, Dialog Datastar, EBSCO Biomedical, ERIC, First Search, Scholar Google, BioRxiv, MedRxiv y el sistema de vigilancia de la Organización Mundial de la Salud (OMS), la Organización Panamericana de la Salud (OPS), el Centro Europeo para la Prevención y Control de Enfermedades (CEPCE). A través de las siguientes palabras claves: "SARS-CoV-2," "COVID19," "manifestaciones neurológicas" y "asociaciones neurológicas"; entre diciembre de 2019 y abril de 2020. Las listas de referencias de los artículos seleccionados fueron buscadas manualmente para cualquier dato relevante. No hubo restricción para la revisión del estudio en los artículos buscados. La búsqueda bibliográfica fue iterativa, es decir, encontrando materiales hasta alcanzar la saturación teórica.

\section{Resultados}

Encontramos 24 artículos relevantes para nuestra búsqueda. Huang et al. . fue el primero que reportó las características clínicas de 41 pacientes confirmados con COVID-19 el 24 de enero del 2020, 8\% de éstos presentó cefalea. Posteriormente en el mismo mes, Chen et al? describió una muestra de 99 pacientes en la cual $8 \%$ presentó cefalea, $9 \%$ alteración de la consciencia y $11 \%$ mialgia. Once estudios fueron publicados en febrero; la manifestación más reportada fue cefalea (4 - 34\%), seguida de mialgia (3.36 - 52

\section{Introduction}

In December 2019, pneumonia cases of unknown etiology were identified in Wuhan city, Hubei Province of China. The cause, a novel enveloped RNA betacoronavirus which was isolated on January 7, 2020, later named Severe Acute Respiratory Syndrome Coronavirus 2 (SARS-CoV-2). On February 11th, The World Health Organization (WHO) defined the condition caused by this pathogen as "Coronavirus disease 2019" (COVID19).! On February 27th, the first case in South America was confirmed in Brazil ${ }^{2}$ and two days later, Ecuador's ${ }^{3}$ first case was reported as well. On March 11th, the WHO declared COVID-19 as a pandemic.4 During this outbreak, numerous studies have mainly described respiratory and gastrointestinal symptoms, distinctive laboratory findings, and characteristic pulmonary radiological abnormalities. But recently, Mao et al reported the first description (preprint) in February 2020 (now published in JAMA Neurology in April), focusing on neurological manifestations of SARS-CoV-2 infection.

\section{Objective}

To summarize the reported neurological manifestations caused by SARS-CoV-2 infection.

\section{Methods}

Three independent searches by authors (DMZ, MAM, and $A F B)$ of articles published in English and Spanish were performed in electronic databases, including Medline, EMBASE, BEI, Cochrane Library, Dialog Datastar, EBSCO Biomedical, ERIC, First Search, Scholar Google, BioRxiv, MedRxiv, and the surveillance system of the World Health Organization (WHO), the Pan American Health Organization (PAHO), the European Center for Disease Prevention and Control (CEPCE). Using the following keywords: "SARS-CoV-2," "COVID-19," "neurological manifestations," and "neurological associations"; between December 2019 and April 2020. The reference list of the selected articles was manually searched for any relevant data. There was no restriction for the review of the study in the articles searched. The bibliographic search was iterative, that is, finding materials until reaching theoretical saturation.

\section{Results}

We found a total of 24 relevant articles in our search. Huang et al. were the first to report the clinical characteristics of 41 patients with confirmed COVID-19 on January 24, 2020, 8\% of which presented with headache. Later in the month, Chen et al? described a sample of 99 patients in which $8 \%$ exhibited headache, 9\% consciousness impairment, and 11\% myalgia. Eleven more studies were published by February; the most common manifestation reported was headache (4 - 34\%), fol- 
\%); ${ }^{1,5,8-18}$ entre esos estudios, el 25 de febrero Mao et al. publicó en línea a través de una base de datos de preimpresión (no revisado por pares) y posteriormente publicada en el JAMA Neurology de abril, el primer reporte con un enfoque neurológico. Dicho estudio contó con una muestra de 214 pacientes, en el cual el $36.4 \%$ tuvo manifestaciones neurológicas que estaban relacionadas de forma directamente proporcional a la severidad del cuadro clínico; entre las cuales se incluyen: mareo $(16.8 \%)$, cefalea $(13.1 \%)$, injuria muscular $(10.7 \%)$, alteración de la consciencia (7.5\%), hipogeusia $(5.6 \%)$, hiposmia $(5.1 \%)$, enfermedad cerebrovascular aguda $(2.8 \%)$, neuralgia $(2.3 \%)$, alteración de agudeza visual $(1.4 \%)$, ataxia $(0.5 \%)$, y crisis epilépticas $(0.5 \%)$. En marzo, 6 estudios $^{17-22}$ similares a los anteriores reportaron como síntoma más común el compromiso muscular (5.49 - 61\%), seguido de cefalea (7.69$13 \%$ ) y mareo (2.4\%). Entre estos, Li et al, ${ }^{17}$ describió en un abstracto disponible en la base de datos de preimpresión de la revista Lancet el desarrollo de eventos cerebrovasculares en pacientes con COVID-19; en el cual, de 221 sujetos, el 5\% presentó evento cerebrovascular isquémico agudo, $0.5 \%$ trombosis de seno cavernoso y $0.5 \%$ hemorragia cerebral. Estos pacientes tenían mayor probabilidad de presentar factores de riesgo cardiovascular e infección por SARS-CoV-2 severa. En abril, Lechien et al mostró que hasta un $85.6 \%$ y $88 \%$ de pacientes podrían presentar disfunciones olfatorias y gustativas respectivamente. ${ }^{23}$ Estos hallazgos están resumidos en la Tabla 1. Recientemente, Li et al mencionó un posible Síndrome de Hipoventilación Central, en una paciente femenina de 24 años, ${ }^{24}$ Jin et al un caso de rabdomiólisis en un hombre de 60 años, ${ }^{25}$ Filatov et al un caso de encefalopatía en un hombre de 74 años, ${ }^{26}$ Poyiadji et al una mujer que desarrolló una Encefalopatía Necrotizante Hemorrágica Aguda, ${ }^{27}$ Zhao et al reportó una mujer de 61 años que presentó Sindrome de Guillain Barré (SGB) durante COVID-19 $9^{28}$ y Moriguchi et al el primer caso de meningitis y encefalitis asociado a la infección por SARS-CoV-2. ${ }^{29}$ Estos casos están presentados en la Tabla 2.

Tabla 1. Manifestaciones neurológicas relacionadas con infección por SARS-CoV-2

\begin{tabular}{|ll|}
\hline & Total (\%) \\
\hline Hipogeusia & $5.6-88$ \\
\hline Hiposmia & $5.1-85.6$ \\
\hline Mialgia & $3.36-61$ \\
\hline Cefalea & $4-34$ \\
\hline Alteración de la Consciencia & $7.5-16.25$ \\
\hline Evento Cerebrovascular & $2.8-6$ \\
\hline Mareo & $2.4-16$ \\
\hline Neuralgia & 2.3 \\
\hline Alteraciones Visuales & 1.4 \\
\hline Ataxia & 0.5 \\
\hline Crisis epilépticas & 0.5 \\
\hline
\end{tabular}

${ }^{*}$ Coronavirus 2 del Síndrome Respiratorio Agudo Severo lowed by myalgia (3.36 - 52\%);,1,5-16 within these

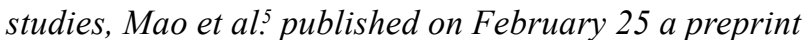
(not peer reviewed) which was later published in JAMA Neurology on April, the first report with a neurological focus. The report consisted of 214 patients, 36.4\% of which had neurological manifestations displaying a direct proportional relation to the severity of the clinical presentations; these included: dizziness (16.8\%), headache (13.1\%), muscle injury (10.7\%), consciousness impairment (7.5\%), hypogeusia (5.6\%), hyposmia (5.1\%), acute cerebrovascular event (2.8\%), neuralgia (2.3\%), visual impairment (1.4\%), ataxia (0.5\%), and seizures $(0.5 \%)$. In March, 6 other similar studies ${ }^{17-22}$ reported muscular compromise as the most common symptom (5.49 - 61\%), followed by headache (7.6913\%), and dizziness (2.4\%). Among these, Li et al. ${ }^{17}$ described in an abstract preprint of the Lancet journal, the development of cerebrovascular events in patients with COVID-19; where 5\% of the 221 subjects included presented with an ischemic stroke, $0.5 \%$ with cavernous sinus thrombosis, and $0.5 \%$ with a cerebral hemorrhage. These patients were more likely to present with cardiovascular risk factors and severe SARS-CoV-2. In April, Lechien et al, showed that up to $85.6 \%$ and $88 \%$ of patients could present olfactory and gustatory dysfunction respectively. ${ }^{23}$ These findings are summarized in Table 1. Recently, Li et al mentioned a possible Central Hypoventilation Syndrome in a 24-year-old female patient, ${ }^{24}$ Jin et al presented a case of rhabdomyolysis in a 60 year old male, ${ }^{25}$ Filatov et al a case of encephalopathy in a 74-year-old man, ${ }^{26}$ Poyiadji et al reported a female that developed acute hemorrhagic necrotizing encephalopathy, ${ }^{27}$ Zhao et al reported a 61 year old female with GBS during COVID-19,28 and Moriguchi et al presented the first case of meningitis and encephalitis associated to SARS-CoV-2 infection. ${ }^{29}$ These cases are presented in Table 2.

Table 1. Neurological Manifestations related to SARS-CoV-2* Infection

\begin{tabular}{|ll|}
\hline & Total (\%) \\
\hline Hypogeusia & $5.6-88$ \\
\hline Hyposmia & $5.1-85.6$ \\
\hline Myalgia & $3.36-61$ \\
\hline Headache & $4-34$ \\
\hline Impaired consciousness & $7.5-16.25$ \\
\hline Cerebrovascular event & $2.8-6$ \\
\hline Dizziness & $2.4-16$ \\
\hline Neuralgia & 2.3 \\
\hline Visual disturbances & 1.4 \\
\hline Ataxia & 0.5 \\
\hline Seizures & 0.5 \\
\hline
\end{tabular}

*Severe Acute Respiratory Syndrome Coronavirus 2 
Tabla 2. Asociaciones Neurológicas Reportadas por Infección SARS-CoV-2*

\begin{tabular}{|c|c|c|c|c|}
\hline Reportes & Autores y Fecha & Sexo & Edad & Comorbilidades \\
\hline Síndrome de Hipoventilación Central \pm & Li et al feb 272020 & Mujer & 24 & No reportado \\
\hline Encefalopatía & Filatov et al mar 212020 & Hombre & 74 & Múltiples** \\
\hline Rabdomiólisis & Jin et al mar 202020 & Hombre & 60 & No reportado \\
\hline Encefalopatía Necrotizante Hemorrágica Aguda & Poyiadji et al mar 312020 & Mujer & No reportado & No reportado \\
\hline Síndrome de Guillain Barré & Zhao et al abr 12020 & Mujer & 61 & No reportado \\
\hline Meningitis & Moriguchi et al abr 32020 & Hombre & 24 & No reportado \\
\hline Encefalitis & Moriguchi et al abr 32020 & Hombre & 24 & No reportado \\
\hline
\end{tabular}

${ }^{*}$ Coronavirus 2 del Síndrome Respiratorio Agudo Severo \pm Posible. ${ }^{* *}$ Fibrilación Auricular, Enfermedad Cerebrovascular Isquémica, Enfermedad de Parkinson, Enfermedad Pulmonar Obstructiva Crónica.

Table 2. Neurological Associations Reported for SARS-CoV-2 Infection *

\begin{tabular}{|c|c|c|c|c|}
\hline Reports & Authors and Date & Sex & Age & Comorbidities \\
\hline Central Hypoventilation Syndrome \pm & Li et al Feb 272020 & Female & 24 & Not reported \\
\hline Encephalopathy & Filatov et al Mar 212020 & Male & 74 & Multiple $^{* *}$ \\
\hline Rhabdomyolysis & Jin et al Mar 202020 & Male & 60 & Not reported \\
\hline Acute Hemorrhagic Necrotizing Encephalopathy & Poyiadji et al Mar 312020 & Female & Not reported & Not reported \\
\hline Guillain Barre syndrome & Zhao et al Apr 12020 & Female & 61 & Not reported \\
\hline Meningitis & Moriguchi et al Apr 32020 & Male & 24 & Not reported \\
\hline Encephalitis & Moriguchi et al Apr 32020 & Male & 24 & Not reported \\
\hline
\end{tabular}

* Severe Acute Respiratory Syndrome Coronavirus 2. \pm Possible. ** Atrial Fibrillation, Ischemic Cerebrovascular Disease, Parkinson's Disease, Chronic Obstructive Pulmonary Disease.

\section{Discusión}

En octubre de 2007, Cheng et al alarmó sobre la importancia de estar listos ante la posibilidad de un brote causado por coronavirus (CoVs) similares al Coronavirus del Síndrome Respiratorio Agudo Severo (SARS-CoV) y al Coronavirus del Síndrome Respiratorio de Oriente Medio (MERS-CoV); debido a la capacidad genética recombinante de estos, a la presencia de reservorios en murciélagos herradura y a la cultura de consumir mamíferos exóticos en el sur de China. Lo llamó "una bomba de tiempo" y exhortó que la necesidad de estar preparados no debía de ser ignorada.$^{30}$ Trece años después, nos enfrentamos a una pandemia por el nuevo coronavirus SARS-CoV-2. Aunque las principales manifestaciones sean de tipo respiratorio, existen reportes de otras presentaciones como por ejemplo las gastrointestinales $(6.1 \%)^{31}$ y cardíacas. ${ }^{32}$ Sin embargo, a medida que aumente el número de infecciones, sería posible observar otras presentaciones menos comunes, incluso aquellas que podrían afectar al sistema nervioso.

El potencial neuroinvasivo del SARS-CoV-2 ha sido previamente postulado, ${ }^{243}$ pero no demostrado. Una vez transmitido a través de gotas respiratorias, aerosoles o contacto, el SARS-CoV-2 entra a las células del huésped mediante el receptor de enzima convertidora de angiotensina 2 (ECA 2); el cual es ampliamente expresado en varios tejidos incluyendo vía respiratoria, pulmones, endotelio y sistema nervioso central (SNC). Estudios en

\section{Discussion}

In October 2007, Cheng et al warned about the importance of public health preparedness for a coronavirus outbreak similar to the Severe Acute Respiratory Syndrome Coronavirus (SARS-CoV) and the Middle East Respiratory Syndrome Coronavirus (MERS-CoV); this is due to the recombinant genetic capacity of these viruses, the presence of reservoirs in horseshoe bats, and the tradition of exotic mammal consumption in the southern China. He called it a "time bomb" and stressed on the need to be prepared for such an event should not be ignored. Today, 13 years later, we face a pandemic caused by the novel coronavirus SARS-CoV-2. Even though the main clinical manifestations are respiratory, there are reports on other clinical presentations such as the gastrointestinal $(6.1 \%)^{31}$ and cardiac as well. ${ }^{32}$ However, as the infection toll rises, other less common clinical presentations may surface, including those of neurological characteristics in nature.

The neuroinvasive potential of SARS-CoV-2 has been previously postulated, ${ }^{24,33}$ but not demonstrated. Once transmitted through respiratory droplets, aerosol, or by direct contact, SARS-CoV-2 enters the host's cells through the angiotensin-converting enzyme receptor 2 (ACE 2); which is widely expressed in various tissues including the respiratory tract, lungs, endothelium, and the central nervous system (CNS). Animal studies have shown various pathways by which coronaviruses could enter the CNS. Either through the olfactory nerves, invading areas such 
animales han demostrado varias vías por las que los coronavirus podrían entrar al SNC. Ya sea a través de los nervios olfatorios, invadiendo áreas como el tallo encefálico y tálamo; o mediante invasión en terminales nerviosas periféricas y luego ganando acceso al SNC a través de una ruta sináptica desde el sistema respiratorio, una vez que haya interactuado con el receptor ECA $2{ }^{33}$ Evidencia disponible cita a coronavirus similares como SARS-CoV, MERS-CoV, Virus de Encefalomielitis Hemaglutinante 67 (HEV67), Coronavirus Humano OC43 (HCV-OC43) o el Virus de Bronquitis Aviar (VBA). En estos estudios, antígenos virales han sido detectados en el tallo encefálico, sobre todo en regiones que incluyen el tracto solitario y núcleo ambiguo. El núcleo del tracto solitario recibe información sensorial de mecanorreceptores y quimiorreceptores pulmonares y tracto respiratorio; mientras fibras eferentes del núcleo ambiguo y del núcleo del tracto solitario proveen de inervación a glándulas, músculo liso de la vía aérea y vasos sanguíneos. Tales interconexiones neuroanatómicas podrían indicar que la muerte de animales infectados o incluso de humanos puede deberse a disfunción de los centros cardiorrespiratorios en el tallo encefálico, apuntando que la disfunción respiratoria en COVID-19 podría tener un componente neurogénico. ${ }^{24}$

Aunque no exista hasta el momento amplia evidencia publicada de neuroinvasión por el SARS-CoV-2, reportes de manifestaciones neurológicas en pacientes hospitalizados con COVID-19 han empezado a surgir, ${ }^{5,17,23-29}$ Estas manifestaciones parecen ser más probables en pacientes con factores de riesgo como hipertensión arterial, diabetes mellitus, enfermedad cerebrovascular previa, edad avanzada, cuadros clínicos severos, linfopenia, proteína $\mathrm{C}$ reactiva y Dímero D elevados. Además, estos pacientes podrían presentar menos síntomas típicos como fiebre y tos, pero ser más probables de presentar injuria muscular, alteración de la consciencia y enfermedad cerebrovascular aguda; éste último podría estar asociado a un estado hipercoagulable tal vez relacionado a elevaciones de Dímero-D, 5,17

Las manifestaciones musculoesqueléticas son comunes en COVID-19. La injuria muscular con elevación de niveles de creatina quinasa y lactato deshidrogenasa se observó en pacientes graves; ${ }^{5}$ su presencia toma importancia ya que se conoce que una posible complicación es la rabdomiólisis.5 Hiposmia y disgeusia han sido recientemente señalados por la Sociedad Española de Neurología y otras sociedades médicas como síntomas de infección por SARS-CoV-2 $3{ }^{34}$ y que su presencia podría alcanzar un $85.6 \%$ y $88 \%$ respectivamente. ${ }^{23}$ La primera, podría ser explicada por la tendencia de los CoVs de invadir los bulbos olfatorios ${ }^{23}$ y su potencial de comprometer SNC. La alteración de la consciencia se ha demostrado como otra manifestación de COVID-19; ésta podría deberse a afectación directa o indirecta, ya que hay reportes en los cuales se detectó el virus en el líquido cefalorraquídeo en un paciente as the brainstem and thalamus; or by invading peripheral nerve terminals and then gaining access to the CNS using a synaptic pathway through the respiratory system, once it has already established contact with the ACE 2 receptor. ${ }^{33}$ Available evidence cites similar coronaviruses such as SARS-CoV and MERS-CoV, Hemagglutinating Encephalomyelitis Virus 67 (HEV67), Human Coronavirus OC43 (HCV-OC43) or Avian Bronchitis Virus $(A B V)$. In these studies, viral antigens have been detected in the brainstem, especially in regions that include the solitary tract and the ambiguous nucleus. The nucleus of the solitary tract receives sensory information from lung mechanoreceptors and chemoreceptors, and the respiratory tract; while efferent fibers from the nucleus ambiguous and the solitary tract nucleus provide innervation to glands, airway smooth muscle and blood vessels.

Such neuroanatomical interconnections could indicate that the death of infected animals or even humans may be due to dysfunction of the cardiorespiratory centers in the brainstem, pointing out that the respiratory dysfunction in COVID-19 may have a neurogenic component. ${ }^{24}$

Although there is no abundant evidence to date regarding neuroinvasion by SARS-CoV-2, reports of neurological manifestations in hospitalized patients with COVID-19 have begun to emerge, ,17,23-29 $^{\text {These manifes- }}$ tations seem to more likely present in patients with risk factors such as high blood pressure, diabetes mellitus, previous cerebrovascular disease, advanced age, severe clinical conditions, lymphopenia, elevated C-reactive protein and D-Dimer. These patients may have fewer typical symptoms such as fever and cough, but are more likely to have muscle injury, impaired consciousness, and acute cerebrovascular disease; the latter could be associated with a hypercoagulable state demonstrated by D-Dimer elevations, ${ }^{5,17}$

Musculoskeletal manifestations are common in COVID-19. Muscle injury with elevated creatine kinase and lactate dehydrogenase levels was observed in severely ill patients, ${ }^{5}$ its presence becomes important since it is known that a possible complication is rhabdomyolysis. ${ }^{25}$ Hyposmia and dysgeusia have recently been reported by the Spanish Society of Neurology and other medical societies as symptoms of SARS-CoV-2 infection, ${ }^{34}$ and that their presence could reach $85.6 \%$ and $88 \%$ respectively. ${ }^{23}$ The first could be explained by CoVs' tendency to invade the olfactory bulbs ${ }^{23}$ and it's potential to compromise the CNS. Consciousness impairment has been demonstrated as another manifestation of COVID19; it could be due to direct or indirect involvement, since there are reports in which the virus was detected in the cerebrospinal fluid in a patient with meningoencephalitis ${ }^{29}$ and not in the other. ${ }^{26}$ In these cases, headache could be a symptom of meningeal involvement, ${ }^{35}$ especially if it presents with neck 
con meningoencefalitis ${ }^{29} \mathrm{y}$ en otro $n 0^{26}$ En estos casos la cefalea podría ser un síntoma de compromiso meníngeo ${ }^{35}$ sobre todo si se presenta con rigidez de nuca (RN) [29]; observación clínica interesante ya que la mayoría de las meningitis virales no presentan RN y este signo ha sido observado en meningitis por SARS-CoV-2. COVID-19 ha sido asociado a actividad epileptógena $(0.5 \%)^{5}$ que podría indicar injuria directa en lóbulo temporal a causa de encefalitis. ${ }^{29}$ Además de ser encontrado en lágrimas, existe evidencia de que el SARS-Cov-2 puede comprometer la conjuntiva, ${ }^{36}$ lo que a su vez podría ser el origen de la hipopsia (disminución agudeza visual). Aunque en la actualidad, la lesión en retina y nervio óptico solo se ha demostrado por otros CoVs. ${ }^{37}$ Asimismo, ataxia y mareo ya han sido previamente descritos en infecciones por CoVs similares. ${ }^{38}$

Un hecho significativo, es que el SARS-CoV-2 se ha relacionado con casos de Encefalopatía Necrotizante Hemorrágica Aguda $^{27}$ y SGB ${ }^{28}$ Otras complicaciones asociadas y post-infecciosas, ya han sido reportadas con otros CoVs como Encefalitis, Polineuromiopatía de Enfermedad Crítica, miopatía, Estado Epiléptico Refractario, Parálisis Flácida Aguda Indeterminada, Encefalitis de Tallo Encefálico, Encefalomielitis Diseminada Aguda y el SGB (Tabla 3). ${ }^{38-46}$ Esta última toma especial importancia, ya que la neuralgia ${ }^{5}$ es una manifestación neurológica periférica observada en COVID19. Proponiendo que además de la virulencia aguda, habría complicaciones crónicas; esto concuerda con evidencia existente que ha demostrado la presencia persistente en glia y posiblemente en neuronas de CoVs similares que estarían relacionados con cambios neuropatológicos perennes. ${ }^{47}$

Los reportes de compromiso neurológico en COVID-19 van en aumento. El reconocimiento oportuno del mismo es significativo ya que es más común en pacientes con cuadros clínicos graves y atípicos, que podrían darse en ausencia de manifestaciones respiratorias o gastrointestinales. Los proveedores de la salud y neurólogos deben prestar atención cercana a esto y deben tener un alto índice de sospecha al evaluar pacientes en un área endémica; sobre todo porque el conocimiento de esto está en evolución. La identificación eficaz podría dar inicio al tratamiento precoz y al aislamiento temprano; previniendo un agravamiento clínico y diseminación del virus. ${ }^{48}$ Actualmente, por restricciones de movilidad y de clínicas de consulta externa, la atención electiva no está ampliamente disponible. Debido a esto, el uso de telemedicina es una necesidad creciente y actualmente se han desarrollado guías para el manejo de COVID-19 para dicho propósito. ${ }^{49}$ Es probable que esta pandemia catalice la amplia adopción de la teleneurología durante y posterior a que el control público de esta enfermedad se haya logrado, ${ }^{50}$ ya que especialistas en neurología no siempre podrían estar disponibles presencialmente para la evaluación de los casos. El conocimiento pleno de estas manifestaciones y asociaciones ayudará a brindar mejor atención a los pacientes, ya sea a través de telemedicina u hospitalariamente. stiffness (NS);29 an interesting clinical manifestation since most viral meningitis do not present NS and this sign has been observed in SARS-CoV-2 meningitis. COVID-19 has been associated with epileptogenic activity $(0.5 \%)^{5}$ that could indicate direct injury to the temporal lobe due to encephalitis. ${ }^{29}$ In addition to being found in tears, there is evidence that SARS-CoV-2 can compromise the conjunctiva, ${ }^{36}$ which in turn could be the origin of hypopsy (decreased visual acuity).

Although to the moment, injury to the retina and optic nerve has only been demonstrated by other CoVs. ${ }^{37}$ Also, ataxia and dizziness have previously been described in similar CoVs infections. ${ }^{38}$

A significant fact is that SARS-CoV-2 has been associated with cases of Acute Hemorrhagic Necrotizing Encephalopathy ${ }^{27}$ and GBS. ${ }^{28}$ Other associated and postinfectious complications have already been reported with other CoVs such as encephalitis, Critical Illness Polyneuromyopathy, myopathy, Refractory Epileptic Status, Indeterminate Acute Flaccid Paralysis, Brainstem Encephalitis, Acute Disseminated Encephalomyelitis, and GBS (Table 3). ${ }^{38-46}$ The latter takes on special importance, since neuralgia ${ }^{5}$ is a peripheral neurological manifestation observed in COVID-19. Proposing that in addition to acute virulence, there could be chronic complications; this is in accordance with existing evidence that has demonstrated the persistent presence in glia and possibly in similar CoVs neurons that would be related to perennial neuropathological changes. ${ }^{47}$

Reports of neurological compromise on COVID-19 are on the rise. Timely recognition is significant since it is more common in patients with severe and atypical clinical conditions, ${ }^{5}$ which could occur in the absence of respiratory or gastrointestinal manifestations. Healthcare providers and neurologists should pay close attention to this and should have a high index of suspicion when evaluating patients in an endemic area; especially since the knowledge of this is evolving. Effective identification could initiate early treatment and early isolation; preventing a clinical aggravation and spread of the virus..$^{4}$ Currently, due to mobility restrictions and lack of service provided by outpatient clinics, elective care is not extensively available. Because of this, the use of telemedicine is a growing need and guidelines for the management of COVID-19 have currently been developed for this purpose..$^{49}$ This pandemic is likely to catalyze the widespread adoption of teleneurology during and after the public control of this disease has been achieved; ${ }^{50}$ since specialists in neurology may not always be readily available in person for the evaluation of cases. Detailed knowledge of these manifestations and associations will help to provide better care to patients, either through telemedicine or inpatient care. 
Tabla 3. Asociaciones Neurológicas Reportadas por Infección por otros Coronavirus.

\begin{tabular}{|c|c|c|c|c|c|}
\hline Reportes & Autores y Fecha & Sexo & Edad $^{+}$ & Comorbilidaes & Coronavirus \\
\hline \multirow{2}{*}{ Encefalitis } & Hung et al 2003 \& & Mujer \& & $59 \& 11$ & Nefropatía IgA \& & SARS $-\mathrm{CoV}^{* *} \&$ \\
\hline & Morfopoulou et al 2016 & Hombre & meses & SICS. ${ }^{*}$ & $\mathrm{HCoV}-\mathrm{OC} 43 \Sigma$ \\
\hline Polineuropatía y Miopatía de Enfermedad Crítica & Tsai et al 2004 & Mujer & $51,48 \& 42$ & No reportada & SARS $-\mathrm{CoV}^{* *}$ \\
\hline Miopatía & Tsai et al 2004 & Hombre & 31 & No reportada & SARS - CoV** \\
\hline Estado Epiléptico Refractario & Lau et al 2004 & Mujer & 32 & $\begin{array}{l}\text { Embarazo de } 26 \\
\text { semanas }\end{array}$ & SARS - CoV** \\
\hline \multirow[t]{2}{*}{ Parálisis Flácida Aguda Indeterminada } & Turgay et al 2015 & Mujer & 3 & No reportada & $\mathrm{HCoV}-\mathrm{OC} 43^{\Sigma} \&$ \\
\hline & & & & & $\mathrm{HCoV}-229 \mathrm{E} f$ \\
\hline Encefalomielitis Aguda Diseminada Severa & $\begin{array}{l}\text { Yeh et al } 2004 \& \text { Arabi } \\
\text { et al } 2017\end{array}$ & Hombre & $15 \& 74 ; 45$ & $\begin{array}{l}\text { No reportada \& DM, } \\
\text { HTN, HLD; DM, } \\
\text { HTN, ERC, EIC.* }\end{array}$ & $\begin{array}{l}\text { HCoV-229Ef \& } \\
\text { MERS-CoV }+\end{array}$ \\
\hline Vasculopatía del Sistema Nervioso Central & Arabi et al 2017 & Hombre & 57 & DM, HTN, EVP* & MERS-CoV + \\
\hline Encefalitis de Tallo Encefálico Post-Infeccioso & Kim et al 2017 & Hombre & 55 & $\mathrm{FA}, \mathrm{DM}, \mathrm{HTN}, \mathrm{ERC}, \mathrm{HTR}^{*}$ & MERS-CoV + \\
\hline \multirow[t]{2}{*}{ Síndrome de Guillain Barré } & Kim et al 2017 \& & Hombre & $55 \& 5$ & FA, DM, HTN, ERC, & MERS-CoV+ \& \\
\hline & Sharma et al 2019 & & & HTR $^{*}$ \& No reportada & $\mathrm{HCoV}-\mathrm{OC} 43 \Sigma$ \\
\hline
\end{tabular}

+Expresado en años a menos que se indique lo contrario. *SICS (Síndrome de Inmunodeficiencia Combinada Severa), DM (Diabetes Mellitus), HTN (Hipertensión), HLD (Hiperlipidemia), ERC (Enfermedad Renal Crónica), EIC (Enfermedad Isquémica Cardiaca), FA (Fibrilación Auricular), HTR (Hipotiroidismo), EVP (Enfermedad Vascular Periférica); **SARS-CoV (Coronavirus del Síndrome Respiratorio Agudo Severo); $\sum$ Coronavirus Humano OC43, $f$ Coronavirus Humano 229E † Coronavirus del Síndrome Respiratorio de Oriente Medio.

Table 3. Neurological Associations Reported by Infection with other Coronaviruses.

\begin{tabular}{|c|c|c|c|c|c|}
\hline Reports & Authors and Date & Sex & Age $^{+}$ & Comorbidities & Coronavirus \\
\hline \multirow[t]{2}{*}{ Encephalitis } & Hung et al 2003 \& & Female \& & $59 \& 11$ & IgA Nephropathy \& & $\mathrm{SARS}-\mathrm{CoV}^{* *} \&$ \\
\hline & Morfopoulou et al 2016 & Male & months & SCID. * & $\mathrm{HCoV}-\mathrm{OC} 43 \Sigma$ \\
\hline Critical Illness Polyneuromyopathy & Tsai et al 2004 & Female & $51,48 \& 42$ & Not reported & SARS $-\mathrm{CoV}^{* *}$ \\
\hline Myopathy & Tsai et al 2004 & Male & 31 & Not reported & SARS - CoV** \\
\hline Refractory Epileptic Status & Lau et al 2004 & Female & 32 & 26 Week Pregnancy & SARS - CoV** \\
\hline \multirow[t]{2}{*}{ Indeterminate Acute Flaccid Paralysis } & Turgay et al 2015 & Female & 3 & Not reported & $\mathrm{HCoV}-\mathrm{OC} 43 \Sigma \&$ \\
\hline & & & & & $\mathrm{HCoV}-229 \mathrm{E} f$ \\
\hline \multirow[t]{2}{*}{ Severe Acute Disseminated Encephalomyelitis } & Yeh et al 2004 \& Arabi & Male & $15 \& 74 ; 45$ & Not reported \& DM, & HCoV-229E $f$ \& \\
\hline & et al 2017 & & & $\begin{array}{l}\text { HTN, HLD; DM, HTN, } \\
\text { CKD, IHD.* }\end{array}$ & MERS-CoV $\dagger$ \\
\hline Central Nervous System Vasculopathy & Arabi et al 2017 & Male & 57 & DM, HTN, PVD* & MERS-CoV $\dagger$ \\
\hline Post-Infectious Brain Stem Encephalitis & Kim et al 2017 & Male & 55 & $\mathrm{AF}, \mathrm{DM}, \mathrm{HTN}, \mathrm{ERC}, \mathrm{HT}^{*}$ & MERS-CoV $\dagger$ \\
\hline \multirow[t]{2}{*}{ Guillain Barré Syndrome } & Kim et al 2017 \& & Male & $55 \& 5$ & FA, DM, HTN, ERC, & MERS-CoV+\& \\
\hline & Sharma et al 2019 & & & $\mathrm{HT}^{*}$ \& Not reported & 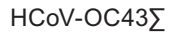 \\
\hline
\end{tabular}

+Expressed in years unless otherwise stated. *SCID (Severe Combined Immunodeficiency Disease), DM (Diabetes Mellitus), HTN (Hypertension), HLD (Hyperlipidemia), CKD (Chronic Kidney Disease), IHD (Ischemic Heart Disease), FA (Atrial Fibrillation), HT (Hypothyroidism), PVD (Peripheral Vascular Disease); **SARS-CoV

(Severe Acute Respiratory Syndrome Coronavirus); $\Sigma$ Human Coronavirus OC43, $f$ Human Coronavirus 229E † Middle East Respiratory Syndrome Coronavirus.

\section{Conclusión}

La infección por SARS-CoV-2 está asociada a compromiso neurológico. Este se observa principalmente en casos severos, en pacientes con comorbilidades y presentaciones atípicas. Proveedores de la salud en general y neurólogos deben prestar atención cercana a esto y tener un alto índice de sospecha debido a la fluidez con la que se reporta nueva información. El reconocimiento oportuno podría ayudar a iniciar tratamiento y aislamiento temprano, previniendo el agravamiento clínico y la propagación del virus.

\section{Conclusion}

SARS-CoV-2 infection is associated with neurological compromise. It is mainly observed in severe cases, in patients with comorbidities, and atypical presentations. General healthcare providers and neurologists should pay close attention to this and have a high index of suspicion due to the fluency with which new information is reported. Timely recognition could help initiate early treatment and isolation, preventing clinical aggravation and spread of the virus. 


\section{Referencias / References}

1. Guan WJ, Ni ZY, Hu Y, et al. Clinical Characteristics of Coronavirus Disease 2019 in China [published online ahead of print, 2020 Feb 28]. N Engl J Med. 2020;10.1056/NEJMoa2002032. doi:10.1056/ NEJMoa2002032

2. World Health Organization. Coronavirus disease 2019 (COVID-19): situation report-38. https:// www.who.int/docs/default-source/coronaviruse/ situation-reports/20200227-sitrep-38-covid-19. pdf?sfvrsn=2db7a09b_4

3. World Health Organization. Coronavirus disease 2019 (COVID-19): situation report-41. https:// www.who.int/docs/default-source/coronaviruse/ situation-reports/20200301-sitrep-41-covid-19. pdf?sfvrsn=6768306d_2

4. World Health Organization. Coronavirus disease 2019 (COVID-19): situation report-51. https:// www.who.int/docs/default-source/coronaviruse/ situation-reports/20200311-sitrep-51-covid-19. pdf?sfvrsn=1ba62e57_10

5. Mao L, Jin H, Wang M, et al. Neurologic Manifestations of Hospitalized Patients With Coronavirus Disease 2019 in Wuhan, China. JAMA Neurol. Published online April 10, 2020. doi:10.1001/jamaneurol.2020.1127

6. Huang C, Wang Y, Li X, et al. Clinical features of patients infected with 2019 novel coronavirus in Wuhan, China [published correction appears in Lancet. 2020 Jan 30;:]. Lancet. 2020;395(10223):497-506. doi:10.1016/S0140-6736(20)30183-5

7. Chen N, Zhou M, Dong X, et al. Epidemiological and clinical characteristics of 99 cases of 2019 novel coronavirus pneumonia in Wuhan, China: a descriptive study. Lancet. 2020;395(10223):507-513. doi:10.1016/ S0140-6736(20)30211-7

8. Wang $\mathrm{D}, \mathrm{Hu} \mathrm{B}, \mathrm{Hu} \mathrm{C}$, et al. Clinical Characteristics of 138 Hospitalized Patients With 2019 Novel Coronavirus-Infected Pneumonia in Wuhan, China [published online ahead of print, 2020 Feb 7]. JAMA. 2020;e201585. doi:10.1001/jama.2020.1585

9. Chang D, Lin M, Wei L, et al. Epidemiologic and Clinical Characteristics of Novel Coronavirus Infections Involving 13 Patients Outside Wuhan, China [published online ahead of print, 2020 Feb 7]. JAMA. 2020;323(11):1092-1093. doi:10.1001/jama.2020.1623

10. COVID-19 National Emergency Response Center, Epidemiology and Case Management Team, Korea Centers for Disease Control and Prevention. Early Epidemiological and Clinical Characteristics of 28 Cases of Coronavirus Disease in South Korea. Osong Public Health Res Perspect. 2020;11(1):8-14. doi:10.24171/j. phrp.2020.11.1.03

11. $\mathrm{Xu} \mathrm{XW}, \mathrm{Wu} \mathrm{XX}$, Jiang $\mathrm{XG}$, et al. Clinical findings in a group of patients infected with the 2019 novel coronavirus (SARS-Cov-2) outside of Wuhan, China: retros- pective case series [published correction appears in BMJ. 2020 Feb 27;368:m792]. BMJ. 2020;368:m606. Published 2020 Feb 19. doi:10.1136/bmj.m606

12. $\mathrm{Xu} \mathrm{YH,} \mathrm{Dong} \mathrm{JH,} \mathrm{An} \mathrm{WM,} \mathrm{et} \mathrm{al.} \mathrm{Clinical} \mathrm{and} \mathrm{computed}$ tomographic imaging features of novel coronavirus pneumonia caused by SARS-CoV-2 [published online ahead of print, 2020 Feb 25]. J Infect. 2020;S01634453(20)30100-6. doi:10.1016/j.jinf.2020.02.017

13. Yang W, Cao Q, Qin L, et al. Clinical characteristics and imaging manifestations of the 2019 novel coronavirus disease (COVID-19):A multi-center study in Wenzhou city, Zhejiang, China [published online ahead of print, $2020 \mathrm{Feb} 26$ ]. J Infect. 2020;S01634453(20)30099-2. doi:10.1016/j.jinf.2020.02.016

14. Tian S, Hu N, Lou J, et al. Characteristics of COVID-19 infection in Beijing [published online ahead of print, 2020 Feb 27]. J Infect. 2020;S0163-4453(20)30101-8. doi:10.1016/j.jinf.2020.02.018

15. $\mathrm{Xu} \mathrm{X}, \mathrm{Yu} \mathrm{C}, \mathrm{Qu} \mathrm{J}$, et al. Imaging and clinical features of patients with 2019 novel coronavirus SARS-CoV-2 [published online ahead of print, $2020 \mathrm{Feb} 28$ ]. Eur J Nucl Med Mol Imaging. 2020;10.1007/s00259-02004735-9. doi:10.1007/s00259-020-04735-9

16. Wu J, Liu J, Zhao X, et al. Clinical Characteristics of Imported Cases of COVID-19 in Jiangsu Province: A Multicenter Descriptive Study [published online ahead of print, 2020 Feb 29]. Clin Infect Dis. 2020;ciaa199. doi:10.1093/cid/ciaa199

17. Li, Yanan and Wang, Mengdie and Zhou, Yifan and Chang, Jiang and Xian, Ying and Mao, Ling and Hong, Candong and Chen, Shengcai and Wang, Yong and Wang, Hailing and Li, Man and Jin, Huijuan and $\mathrm{Hu}$, Bo, Acute Cerebrovascular Disease Following COVID-19: A Single Center, Retrospective, Observational Study (3/3/2020). Preprint at SSRN: https://ssrn. com/abstract $=3550025$

18. Zhao W, Zhong Z, Xie X, Yu Q, Liu J. Relation Between Chest CT Findings and Clinical Conditions of Coronavirus Disease (COVID-19) Pneumonia: A Multicenter Study [published online ahead of print, $2020 \mathrm{Mar} 3$ ]. AJR Am J Roentgenol. 2020;1-6. doi:10.2214/AJR.20.22976

19. Cheng Z, Lu Y, Cao Q, et al. Clinical Features and Chest CT Manifestations of Coronavirus Disease 2019 (COVID-19) in a Single-Center Study in Shanghai, China [published online ahead of print, 2020 Mar 14]. AJR Am J Roentgenol. 2020;1-6. doi:10.2214/ AJR.20.22959

20. Mo P, Xing Y, Xiao Y, et al. Clinical characteristics of refractory COVID-19 pneumonia in Wuhan, China [published online ahead of print, 2020 Mar 16]. Clin Infect Dis. 2020;ciaa270. doi:10.1093/cid/ciaa270

21. Han R, Huang L, Jiang H, Dong J, Peng H, Zhang D. Early Clinical and CT Manifestations of Coronavirus Disease 2019 (COVID-19) Pneumonia [published online ahead of print, 2020 Mar 17]. AJR Am J Roentgenol. 2020;1-6. doi:10.2214/AJR.20.22961 
22. Qian GQ, Yang NB, Ding F, et al. Epidemiologic and Clinical Characteristics of 91 Hospitalized Patients with COVID-19 in Zhejiang, China: A retrospective, multicentre case series [published online ahead of print, 2020 Mar 17]. QJM. 2020;hcaa089. doi:10.1093/qjmed/hcaa089

23. Lechien, J.R., Chiesa-Estomba, C.M., De Siati, D.R. et al. Olfactory and gustatory dysfunctions as a clinical presentation of mild-to-moderate forms of the coronavirus disease (COVID-19): a multicenter European study. Eur Arch Otorhinolaryngol (2020). https://doi. org/10.1007/s00405-020-05965-1

24. Li YC, Bai WZ, Hashikawa T. The neuroinvasive potential of SARS-CoV2 may play a role in the respiratory failure of COVID-19 patients [published online ahead of print, 2020 Feb 27]. J Med Virol. 2020;10.1002/jmv.25728. doi:10.1002/jmv.25728

25. Jin M, Tong Q. Rhabdomyolysis as Potential Late Complication Associated with COVID-19 [published online ahead of print, 2020 Mar 20]. Emerg Infect Dis. 2020;26(7):10.3201/eid2607.200445. doi:10.3201/ eid2607.200445

26. Filatov A, Sharma P, Hindi F, et al. (March 21, 2020) Neurological Complications of Coronavirus Disease (COVID-19): Encephalopathy. Cureus 12(3): e7352. doi:10.7759/cureus.7352

27. Poyiadji N, Shahin G, Noujaim D, Stone M, Patel S, Griffith B. COVID-19-associated Acute Hemorrhagic Necrotizing Encephalopathy: CT and MRI Features [published online ahead of print, 2020 Mar 31]. Radiology. 2020;201187. doi:10.1148/radiol.2020201187

28. Zhao H, Shen D, Zhou H, Liu J, Chen S. GuillainBarré syndrome associated with SARS-CoV-2 infection: causality or coincidence? The Lancet Neurology. 2020 Apr 1;0(0). 10.1016/S1474-4422(20)30109-5

29. Moriguchi T, Harii N, Goto J, et al. A first Case of Meningitis/Encephalitis associated with SARS-Coronavirus-2 [published online ahead of print, 2020 Apr 3]. Int J Infect Dis. 2020;S1201-9712(20)30195-8. doi:10.1016/j.ijid.2020.03.062

30. Cheng VC, Lau SK, Woo PC, Yuen KY. Severe acute respiratory syndrome coronavirus as an agent of emerging and reemerging infection. Clin Microbiol Rev. 2007;20(4):660-694. doi:10.1128/CMR.00023-07

31. Rodriguez-Morales AJ, Cardona-Ospina JA, Gutiérrez-Ocampo E, et al. Clinical, laboratory and imaging features of COVID-19: A systematic review and metaanalysis [published online ahead of print, $2020 \mathrm{Mar}$ 13]. Travel Med Infect Dis. 2020;101623. doi:10.1016/j. tmaid.2020.101623

32. Inciardi RM, Lupi L, Zaccone G, et al. Cardiac Involvement in a Patient With Coronavirus Disease 2019 (COVID-19) [published online ahead of print, 2020 Mar 27]. JAMA Cardiol. 2020;10.1001/jamacardio.2020.1096. doi:10.1001/jamacardio.2020.1096

33. Baig AM, Khaleeq A, Ali U, Syeda H. Evidence of the COVID-19 Virus Targeting the CNS: Tissue Distribution,
Host-Virus Interaction, and Proposed Neurotropic Mechanisms [published online ahead of print, 2020 Mar 13]. ACS Chem Neurosci. 2020;10.1021/acschemneuro.0c00122. doi:10.1021/acschemneuro.0c00122

34. SEN A. Covid-19: Recomendaciones de la Sociedad Española de Neurología (SEN) en relación con la pérdida de olfato como posible síntoma precoz de infección por CoVID-19[Internet]. [cited2020Mar25]. Available from: http:/www.sen.es/noticias-y-actividades/222-noticias/ covid-19-informacion-para-pacientes/2663-covid-recomendaciones-de-la-sociedad-espanola-de-neurologiasen-en-relacion-con-la-perdida-de-olfato-como-posible-sintoma-precoz-de-infeccion-por-covid-19

35. Nath A. Neurologic complications of coronavirus infections. Neurology. 2020 Mar 27;10.1212/ WNL.0000000000009455.

36. Wu P, Duan F, Luo C, et al. Characteristics of Ocular Findings of Patients With Coronavirus Disease 2019 (COVID-19) in Hubei Province, China. JAMA Ophthalmol. Published online March 31, 2020. doi:10.1001/jamaophthalmol.2020.1291

37. Seah I, Agrawal R. Can the Coronavirus Disease 2019 (COVID-19) Affect the Eyes? A Review of Coronaviruses and Ocular Implications in Humans and Animals [published online ahead of print, 2020 Mar 16]. Ocul Immunol Inflamm. 2020;1-5. doi:10.1080/09273 948.2020.1738501

38. Arabi YM, Harthi A, Hussein J, et al. Severe neurologic syndrome associated with Middle East respiratory syndrome corona virus (MERS-CoV). Infection. 2015;43(4):495-501. doi:10.1007/s15010-015-0720-y

39. Hung EC, Chim SS, Chan PK, et al. Detection of SARS coronavirus RNA in the cerebrospinal fluid of a patient with severe acute respiratory syndrome. Clin Chem. 2003;49(12):2108-2109. doi:10.1373/clinchem.2003.025437

40. Morfopoulou S, Brown JR, Davies EG, et al. Human Coronavirus OC43 Associated with Fatal Encephalitis. N Engl J Med. 2016;375(5):497-498. doi:10.1056/ NEJMc1509458

41. Tsai LK, Hsieh ST, Chao CC, et al. Neuromuscular disorders in severe acute respiratory syndrome. Arch Neurol. 2004;61(11):1669-1673. doi:10.1001/archneur.61.11.1669

42. Lau KK, Yu WC, Chu CM, Lau ST, Sheng B, Yuen KY. Possible central nervous system infection by SARS coronavirus. Emerg Infect Dis. 2004;10(2):342-344. doi:10.3201/eid1002.030638

43. Turgay C, Emine T, Ozlem K, Muhammet SP, Haydar AT. A rare cause of acute flaccid paralysis: Human coronaviruses. J Pediatr Neurosci. 2015;10(3):280-281. doi:10.4103/1817-1745.165716

44. Yeh EA, Collins A, Cohen ME, Duffner PK, Faden H. Detection of coronavirus in the central nervous system of a child with acute disseminated encephalomyelitis. Pediatrics. 2004;113(1 Pt 1):e73-e76. doi:10.1542/ peds.113.1.e73 
45. Kim JE, Heo JH, Kim HO, et al. Neurological Complications during Treatment of Middle East Respiratory Syndrome. J Clin Neurol. 2017;13(3):227-233. doi:10.3988/jen.2017.13.3.227

46. Sharma K, Tengsupakul S, Sanchez O, Phaltas $\mathrm{R}$, Maertens P. Guillain-Barré syndrome with unilateral peripheral facial and bulbar palsy in a child: A case report. SAGE Open Med Case Rep. 2019;7:2050313X19838750. Published 2019 Mar 21. doi:10.1177/2050313X19838750

47. Arbour N, Ekandé S, Côté G, et al. Persistent infection of human oligodendrocytic and neuroglial cell lines by human coronavirus 229E. J Virol. 1999;73(4):3326-3337.
48. Jin H, Hong C, Chen S, Zhou Y, Wang Y, Mao L, et al. Consensus for prevention and management of coronavirus disease 2019 (COVID-19) for neurologists. Stroke Vasc Neurol. 2020 Apr 1;svn-2020-000382.

49. Greenhalgh T, Koh GCH, Car J. Covid-19: a remote assessment in primary care. BMJ. 2020;368:m1182. Published 2020 Mar 25. doi:10.1136/bmj.m1182

50. COVID-19 is catalyzing the adoption of teleneurology Brad C. Klein, Neil A. BusisNeurology Apr.2020, 10.1212/WNL.0000000000009494; DOI:10.1212/ WNL.0000000000009494. 